\title{
CORPORATIONS AMENABLE TO SECTION 77B
}

\section{JACOB I. WeINSTEIN $\dagger$}

At the very threshold of the new Corporate Reorganization Section of the Bankruptcy Act, ${ }^{1}$ arises the fundamental question of the scope of the term "corporation", as used in the Section. By the terms of subdivision $a,{ }^{2}$ any corporation which could become a bankrupt under Section $4^{3}$ of the Act, except a railroad subject to the provisions of Section $77^{4}$ and except certain corporations owning or operating railroads or railways in which a municipality has an interest, may file a voluntary proceeding for reorganization. It is also provided that three or more creditors of any corporation may file an involuntary petition for a reorganization with the court in which the debtor corporation may file a petition under the Section, ${ }^{6}$ and that any subsidiary corporation may file an intervening petition for its reorganization in connection with or as a part of the reorganization of its principal. ${ }^{7}$ Superficially, the language of this subdivision would appear to be clear. When studied more carefully, however, it gives rise to a number of troublesome problems. It will be found not only that there are some minor difficulties inherent in the subdivision, but also that the scope of the word "corporation" may itself be susceptible of doubt. Normally, the term has a specific meaning, that of an artificial entity chartered under statute law. ${ }^{8}$ In the Bankruptcy Act, however, the word is given a much broader scope, and by express definition, ${ }^{9}$ includes many bodies which do not come within the ordinary understanding of the term. The parent draft of Section $77 \mathrm{~B}$, as it was contained in the Hastings Bill, ${ }^{10}$

$\dagger$ B. S., 1904, LL. B., 1907, University of Pennsylvania; member of National Bankruptcy Conference; member of Bankruptcy Committee, Commercial Law League of America; author of Redraft of the Bankruptcy Act (1932) 8 A. B. Rev. 389; Chapter VIII of the Bankruptcy Act (1933) 38 Coms. I. J. I7I; On the Meaning and Implications of "Affected" under Section $77 B$ (I934) I CORP. REORG. I83; and of other articles in legal periodicals; member of the Philadelphia Bar.

I. 48 StAT. 9I2, II U. S. C. A. § 207 (Supp. I934).

2. 48 STAt. 9I2, II U. S. C. A. \$207 (a) (Supp. r934). For text, see infra note I8.

3. 30 Stat. 547 (I898), as amended, 32 Stat. 797 (1903), as amended, 36 Stat. 839 (Igro), as amended, 47 STAT. 47 (I932), II U. S. C. A. \$22 (Supp. 1934). For text, see infra note Ig.

4. 47 STAT. I474, II U. S. C. A. \$205 (Supp. I934).

5. Bankruptcy Áct, §77B (n), 48 STAT. 922, II U. S. C. A. \$ 207 (n) (Supp. I934). For text, see infra note 76 .

6. Bankruptcy Act, §77B (a), 48 Stat. 9I2, II U. S. C. A. § 207 (a) (Supp. 1934). For text, see infra note $6 \pi$.

7. Ibid. For text, see infra p. 87I.

8. For a collation of definitions, see I4 C. J. § I (IgI9) ; I Bouv. LAw Dict. (Rawle's 3d ed. rgr4) 682.

9. Bankruptcy Act, $\S$ I (6), 30 STAT. 544 (I898), as amended, 44 STAT. 662 (I926), II U. S. C. A. \& I (6) (Supp. 1934). For text, see infra note I5.

ro. S. 3866 , Senate Committee Print, $72 d$ Cong., Ist Sess. (1932). For text, see infra note 32 . 
recognized this fact and by express language restricted the section to "moneyed, business or commercial corporations, except a municipal, railroad, insurance or banking corporation." However, in subsequent measures, ${ }^{11}$ which expanded upon the original section of the Hastings Bill, the restrictive language was abandoned, and the provision substantially as it now appears in Section $77 \mathrm{~B}$ was substituted.

There is nothing in the reports of the Judiciary Committees ${ }^{12}$ which explains this change. It generally appears to be taken for granted that the term "corporation", as used in the Section, means a private business corporation, in the strict or limited sense. ${ }^{13}$ This assumption would seem to find some warrant in the general tenor of the Section. On the other hand, Judge McKeown, formerly Chairman of the Subcommittee on Bankruptcy of the Judiciary Committee of the House of Representatives, which had before it for consideration the series of measures culminating in Section $77 \mathrm{~B}$, asserts categorically that the term is used in the broad bankruptcy sense. ${ }^{14}$

It is the purpose of this discussion to consider in detail the various aspects of this question, as well as a number of subsidiary questions raised by the Section.

\section{The Meaning and Scope of the Term "Corporation"}

Section $77 B$ nowhere expressly defines the term "corporation." However, the Bankruptcy Act does define the term in the section dealing with "Words and Phrases", ${ }^{15}$ and includes within such definition not only corpo-

II. See infra pp. 857 et seq.

12. H. R. REP. No. 1897, 72d Cong., 2d Sess., Ser. No. 9649 (1933) ; Sen. Rep. No. I215, 72 d Cong., 2 d Sess., Ser. No. 9647 (I933) ; H. R. REp. No. 194, 73d Cong., Ist Sess., Ser. No. 9774 (I933) ; SEN. REP. No. 482, 73d Cong., 2d Sess., Ser. No. 9769 (1934); H. R. REP. No. 1773, 73d Cong., 2d Sess., Ser. No. 9776 (1934).

I3. Jackson, Analysis of the Corporate Bankruptcy Act (1934): 92 N. Y. L. J. 80, 92, I02; Walker, Corporate Rehabilitation under New Bankriptcy Law (I934) 59 TRust Cos. 5; Burns, The Corporate Reorganization Act (I934) 39 Comm. L. J. 375; Weiner, Corporate Reorganization: Section $77 B$ of the Bankruptcy Act (I934) 34 CoL. L. REv. II73; Kaplan, Corporate Reorganization under Section $77 B$ (I934) 33 MICH. L. Rev. 77; Friendly, Sone Comments on the Corporate Reorganizations Act (I934) 48 HARv. L. REv. 39; Corporate Reorganizations Law (1934) 68 U. S. L. REv. 291 ; Ernst, Corporate Reorganizations under the Bankruptcy Amendments (I934) 68 U. S. L. REv. 47I; Grant, Corporate Reorganizations under the Recent Amendments to the Federal Bankruptcy Act (1934) 20 CoRN. L. Q. 95; The I933 and I934 Amendments to the Bankruptcy Act (1934) 2I VA. L. REv. 86; Spaeth, The Reorganization Amendments to the Bankruptcy Act (1934) 8 TEMPLE I. Q. 447; Kahn, The New Corporate Reorganization Statute (I934) 9 J. Nat. Ass'N ReF. BKcy. II; Gerdes, Constitutionality of Section $77 B$ of the Bankruptcy Act (1934) I2 N. Y. U. L. Q. Rev. I96; Oliver, The Corporate Reorganization Amendment to the Bankruptcy Act (1935) 9 TEMPLE L. Q. I44; Hanna, Corporate Reorganization under the Bankruptcy Act (I933) 2r A. B. A. J. 73. However, Stanley L. Sabel (The Corporate Reorganizations Act (1934) I9 MinN. L. Rev. 34, 54) recognizes that the term "corporation" is used here in the broad bankruptcy sense.

14. McKeown and Langeluttig, Federal Debtor Relief Laws (1935) to8, Iog.

15. Bankruptcy Act, \& I, 44 Stat. 662 (I926), II U. S. C. A. \& I (Supp. I934) :"a. The words and phrases used in this Act and proceedings pursuant hereto shall, unless the same be inconsistent with the context, be construed as follows: ... (6) 'corporations' shall mean all bodies having any of the powers and privileges of private corporations not possessed by individuals or partnerships and shall include limited or other partnership associations or- 
rations in the strict sense of the term, but also other groups possessing some of the characteristics of private corporations. Since Section $77 \mathrm{~B}$ is an integral part of the Act, ${ }^{16}$ and since subdivision $k$ of that Section ${ }^{17}$ makes all provisions of the Act, unless inconsistent, applicable to the Section, it would follow that unless inconsistent with its context, the definition is applicable to the Section. However, when the general context of the Section is studied, a doubt arises whether the corporations contemplated by the Section include the bodies comprehended within the definition. At various places in the Section there are references to stockholders and to classes and rights of stockholders, to subsidiary corporations having capital stock, to the formation, consolidation and merger of corporations, to charter amendments, to provisions which a plan may or must include in respect to stockholders, and the like. All these features appear to contemplate stock corporations. The courts, therefore, will be obliged to choose between the narrow meaning of the term imported by the general tenor of the Section and the broader definition as given in Section I (6), with such restrictions as are expressly provided by Section $77 \mathrm{~B}$.

\section{A. Language of the Text}

Section $77 B$ permits a voluntary petition to be filed by "any corporation which could become a bankrupt under Section 4 of this Act . . ." 18 When read in conjunction with Section 4, the language is plain and unambiguous, and presents no difficulty. As it reads, all that need be done to determine what corporations may file a petition or answer under Section $77 B$ is to

ganized under laws making the capital subscribed alone responsible for the debts of the associations, joint stock companies, unincorporated companies and associations, and any business conducted by a trustee, or trustees, wherein beneficial interest or ownership is evidenced by certificate or other written instrument."

16. Amendments are to be construed together with the original act to which they relate as constituting one law. United States v. Woolsey, 28 Fed. Cas. No. I6,763 (I846) ; Woodall v. Boston Elec. Ry., I92 Mass. 308, 78 N. E. 446 (Ig06) ; Gas Light Co. v. South River, 77 N. J. Eq. 487, 77 Atl. 473 (rgro) ; People v. Marlin-Rockwell Corp., r33 Misc. 74I, 234 N. Y. Supp. 220 (City Ct. Ig29).

I7. 48 STAT. 92I, II U. S. C. A. $\$ 207$ (k) (Supp. x934), provides in part: "All other provisions of this Act, except such as are inconsistent with the provisions of this section $77 B$, shall apply to proceedings instituted under this section. . . ."

18. Bankruptcy Act, §77B (a), 48 STAT. 9I2, II U. S. C. A. § 207 (a) (Supp. I934) : "Any corporation which could become a bankrupt under section 4 of this Act, and any railroad or other transportation corporation, except a railroad corporation authorized to file a petition or answer under the provisions of section 77 of this Act, and except as hereinafter provided, may file an original petition, or, before adjudication in an involuntary proceeding, an answer, or in any proceeding: pending in bankruptcy, whether filed before or after this section becomes effective, provided the present operations of such corporation do not exclude it hereunder, and whether or not the corporation has been adjudicated a bankrupt, a petition stating the requisite jurisdictional facts under this section; the nature of the business of the debtor; in brief description, the assets, liabilities, capital stock, and financial condition of the debtor; if a prior proceeding is pending, the name of the court in which it is pending and the nature of such proceeding; facts showing the need for relief under this section; and that the corporation is insolvent or unable to meet its debts as they mature and that it desires to effect a plan of reorganization." 
refer to Section 4 to ascertain what corporations may become bankrupt thereunder.

By reference to Section $4,^{19}$ which deals with the persons who may become bankrupts, whether voluntary or involuntary, it is found that subdivision $a$, which relates to voluntary proceedings, permits a bankruptcy petition to be filed by any person, except a municipal, railroad, insurance or banking corporation, or building and loan association; and that subdivision $b$, which relates to involuntary proceedings, permits a bankruptcy petition to be filed against any natural person except a wage-earne: or farmer, any unincorporated company and any moneyed, business or commercial corporation except a building and loan association, a municipal, railroad, insurance or banking corporation. The word "person", as used in subdivision $a$, is defined by Section I (I9) ${ }^{20}$ of the Bankruptcy Act to include a corporation; and the word "corporation", as defined by Section I (6) of the Bankruptcy Act, "means all bodies having any of the powers and privileges of private corporations not possessed by individuals or partnerships", and includes "limited or other partnership associations organized under laws making the capital subscribed alone responsible for the debts of the association, joint stock companies, unincorporated companies and associations, and any business conducted by a trustee or trustees, wherein beneficial interest or ownership is evidenced by certificate or other written instrument."

Thus it will be seen that subdivision $a$ is considerably broader than subdivision $b$, and that a voluntary bankruptcy petition may be filed under subdivision $a$ by persons who cannot be subjected to an involuntary proceeding under subdivision $b$. More particularly, in respect to "corporations", subdivision $a$ permits a voluntary petition to be filed, except as therein specified, ${ }^{21}$ by any corporation in the extremely broad sense of the definition of Section I (6). Consequently, for the purposes of that subdivision, "corporation" includes not only incorporated bodies for profit, but also non-profit incorporated bodies, such as religious, educational, fraternal, char-

I9. 47 Stat. 47 (I932), II U. S. C. A. §22 (Supp. I934) : "a. Any person, except a municipal, railroad, insurance, banking corporation, or a building and loan association, shall be entitled to the benefits of this Act as a voluntary bankrupt.

"b. Any natural person, except a wage earner or a person engaged chiefly in farming or the tillage of the soil, any unincorporated company, and any moneyed, business, or commercial corporation (except a municipal, railroad, insurance, or banking corporation, or a building and loan association), owing debts to the amount of \$1000 or over, may be adjudged an involuntary bankrupt upon default or an impartial trial, and shall be subject to the provisions and entitled to the benefits of this Act."

20. 30 StAT. 545 ( I898), II U. S. C. A. § I (I9) (I927) : “. . . 'persons' shall include corporations, except where otherwise specified, and officers, partnerships, and women, and when used with reference to the commission of acts which are herein forbidden, shall include persons who are participants in the forbidden acts, and the agents, officers, and members of the board of directors or trustees, or other similar controlling bodies of corporations."

2r. I. e., a municipal, railroad, insurance, or banking corporation, or a building and loan association. 
itable and like corporations, ${ }^{22}$ and also includes unincorporated bodies, whether for profit or otherwise, limited partnerships, partnership associations, joint stock companies, common law or Massachusetts trusts, and the like. ${ }^{23}$ On the other hand, subdivision $b$ permits involuntary bankruptcy proceedings only against unincorporated companies, at least those crganized chiefly for a commercial purpose, ${ }^{24}$ and any moneyed, business or commerciai corporation, ${ }^{25}$ except as therein specified. ${ }^{26}$ The language, "any corporation which could become a bankrupt under Section 4 of this Act", obviously may refer either to subdivision $a$ or subdivision $b$ of Section 4. However, from the phrase "any corporation", it is manifest that its proper meaning is in the broadest sense derivable from Section 4, namely, all bodies falling within the wide scope of the definition of "corporation." Such construction gives to the language of the text its natural import.

\section{B. History of Legislation}

Section $77 B$ has its origin in Section 76 of the Hastings Bill, ${ }^{27}$ which was introduced in Congress early in I932, as an aftermath of the Donovan bankruptcy investigation conducted in the Southern District of New York. ${ }^{28}$ The Bill was intended as a complete revision of the Bankruptcy Act, and among its radical innovations contained a new Chapter VIII, entitled "Provisions for the Relief of Debtors." The plan of the Chapter was rather broad; Section I2, ${ }^{29}$ relating to compositions, was eliminated, and four new sections were substituted. ${ }^{30}$ Of these, Section 73 dealt with compositions

22. In re Elmsford Country Club, 50 F. (2d) 238 (S. D. N. Y. I93I) ; In re Carthage Lodge, 230 Fed. 694 (N. D. N. Y. I916); In re Grand Lodge Ancient Order of United Workmen, 232 Fed. Ig9 (N. D. Cal. I916) ; I ColliER, Bankruptcy (I3th ed. I924) I97, 2II; I REAINGTON, BANKRUPTCX (4th ed. I934) 100, IOI, I64.

23. In re Sargent Lumber Co., 287 Fed. I54 (E. D. Ark. 1923) (unincorporated company) ; ColIIER, BANKRUPTCY (I3th ed. I924) I934 Supp. 76.

24. In re Order of Sparta, 242 Fed. 235 (C. C. A. 3d, I9I7); In re Tidewater Coal Exchange, 280 Fed. 638 (C. C. A. 2d, I922); In re William McKinley Lodge, 4 F. Supp. 280 (S. D. N. Y. I933). For cases holding that a Massachusetts or common law trust is included within the meaning of "unincorporated company", see I REMINGTON, BANKRUPTCY (4th ed. 1934) I58, n. 37; Notes (1927) 46 A. L. R. I79; (I929) 58 A. L. R. 523; (I93I) 7I A. L. R. 895 .

25. This language is derived from the National Bankruptcy Act of I867. I4 STAT. 517, c. I76 (I867). For the history of this provision, see In re Columbia Ry., Gas \& Elec. Co., 24 F. (2d) 828 (E. D. S. C. I928). A non-stock, non-profit cooperative corporation is not subject to an involuntary adjudication. In re Dairy Marketing Ass'n of Ft. Wayne, Inc., 8 F. (2d) 626 (D. Ind. I925) ; Ir re Weeks Poultry Community, Inc., 5I F. (2d) I22 (S. D. Cal. I93I). Contra: Schuster v. Ohio Farmers' Coop. Milk Ass'n, 6r F. (2d) 337 (C. C. A. 6th, 1932). See also (1932) 46 HARv. L. REv. 326.

26. I. e., a municipal, railroad, insurance or banking corporation, or a building and loan association.

27. Supra note ro.

28. For a report of the investigation, see (1930) NEW YORK BANKRUPTCY INVESTIGATION D. C. S. D., N. Y.

29. 30 Stat. 549 ( 1898 ), as amended, 36 Stat. 839 (I9I0), as amended, 44 Stat. 663 (1926), II U. S. C. A. \$ 30 (Supp. I934).

30. $\$ 73$, Compositions and Extensions; $\$ 74$, Assignments for the Benefit of Creditors; $\S 75$, Amortization of Debts (by wage earners); $\$ 76$, Corporate Reorganizations. 
and extensions by "any person, except a municipal, railroad, insurance or banking corporation", ${ }^{31}$ and Section 76 , with corporate reorganizations by "any moneyed, business or commercial corporation, except a municipal, railroad, insurance or banking corporation." 32

The Hastings Bill immediately provoked widespread and vigorous opposition, and was permitted to die in Committee. ${ }^{33}$ However, the featured "debtor relief" proposals met with popular favor; and, as the result of a persistent demand, a series of separate measures embodying some of the relief provisions was offered in Congress during the sessions of $1932 .^{34}$ Another and the last of this series, H. R. I4359, was introduced in January I933..$^{35}$ In this measure, Section 74 replaced Section 73 of the Hastings Bill, its scope being enlarged to include secured debts, and its application

3x. $\$ 73$ (a) provided in part: "Any person except a municipal, railroad, insurance or banking corporation may file a petition, or in an involuntary proceeding before adjudication an answer . . . stating that he is insolvent, or unable to meet his debts as they mature, and that he desires to offer a proposal under this Act for a composition or an extension of time to pay his debts."

32. $\$ 76$ (a) provided in part: "Any moneyed, business, or commercial corporation, except a municipal, railroad, insurance, or banking corporation, may file a petition, or, before adjudication in an involuntary proceeding, an answer, stating that the corporation is insolvent or unable to meet its debts as they mature and that it desires to effect a plan of reorganization."

33. The Report of the Solicitor General, "On the Bankruptcy Act and its Administration in the Courts of the United States", SEN. Doc. No. 65, 72 d Cong., Ist Sess., Ser. No. 9507 (I93I), addressed to the President (Dec. 5, I93I), and in turn transmitted to Congress with a Message of the President (Feb. 29, I932), recommended a complete revision of the Bankruptcy Act, in the form subsequently designated as the Hastings Bill. Identical bills drafted by the Department of Justice under Solicitor General Thatcher were introduced virtually simultaneously, S. 3866 in the Senate on February 29, 1932, and H. R. 9968 in the House of Representatives on March I, 1932. These Bills were referred to the Judiciary Committees of the Senate and House respectively, and subcommittees thereof conducted extensive joint hearings during April and May, 1932. Joint Hearings Before the Sub-Committees on the Judiciary on $S$. 3866, 72d Cong., Ist Sess. (I932). The testimony taken at these hearings evidenced the violent controversy on the innovations proposed by the Hastings Bill. See 76 Cong. Rec. 4876 (I933) ; Sen. Rep. No. I2I5, $72 d$ Cong., 2d Sess., Ser. No. 9647 (I933); Garrison, The Power of Congress over Corporate Reorganizations (I933) I9 VA. L. REv. 343; Note (1933) I9 VA. L. REv. 382.

34. Chapter VIII of the Hastings Bill, relating to debtor relief, was rewritten by the Department of Justice, with the inclusion of provisions for the reorganization of railroads, and was introduced in the Senate as a separate bill, S. 492I, on June 2I, I932. On December 29, I932, Representative McKeown introduced $H$. R. I3955, and later H. R. r4I33, both dealing with the subjects of compositions and extensions, and corporate reorganizations. Representative La Guardia introduced H. R. I3958 on December 29, I932, and later H. R. I4IIo, both dealing with the subject of the reorganization of railroads engaged in interstate commerce. These bills were considered by the House Committee on Judiciary in executive session, and after agreement certain portions were all merged into a bill known as H. R. I4359. See infra note 35 and SEN. ReP. No. I215, $72 d$ Cong., 2d Sess., Ser. No. 9647 (I933).

35. The Bill was introduced on January 2I, I933, by Representative Sumners of the House Committee on Judiciary. 76 Cong. Rec. 2242 (1933). The Bill passed the House on January 30, 1933, and then was referred to the Senate Committee on the Judiciary. 76 CoNG. REc. 2931, 2958 (I933). A subcommittee was appointed, which held no hearings, but invited suggestions and criticisms in writing. The House bill was rewritten, and introduced in the Senate on January 28, r933, under the designation S. 555I. The suggestions and criticisms relating to $H$. $R$. 14359 and $S$. $555 I$ are contained in a Senate Committee Print, $72 d$ Cong., $2 d$ Sess. (I933). For further details of the history of the Bill, see SEN. REP. No. I215, 72d Cong., $2 d$ Sess., Ser. No. 9647 (1933). For the debates in Congress, see 76 Cong. Rec. 2907-3I, 2938 (House), 4505, 4876, 4901, 5014, 5I03, 5II7-5I35 (Senate) (I933). 
restricted to "any person excepting a corporation"; 30 and Section 75 replaced Section 76 of the Hastings Bill, and provided for the reorganization of "any corporation which could become a bankrupt under Section 4 of the Act." 37 The repeal of Section I2 was continued. ${ }^{38}$

At this point, it is manifest that by virtue of the repeal of Section I2, the new Sections 74 and 75 were intended to comprise all forms of debtor relief under the Act; that Section 74 was designedly restricted to "persons" other than "corporations"; and that "corporations", in pursuance of the same design, were afforded debtor relief solely by way of corporate reorganization under Section 75. However, it is by no means a simple matter to determine whether the "corporations" referred to in H. R. I4359 included all the various forms of associations comprised within the definition of Section I (6) of the Bankruptcy Act, or were limited to stock corporations in the strict sense. One thing only is certain, that whatever meaning was intended, it was identical in both these sections; for it is inconceivable that the same term was used in different senses in two closely related portions of the same legislative measure. ${ }^{39}$ Furthermore, if the "corporations" excluded from Section 74 were meant to be all groups comprised within the bankruptcy definition, and those included under Section 75 were intended to be only stock corporations in the strict sense, it would follow that the intermediate group of associations comprised within the definition of Section I (6) would be afforded no debtor relief under the Act. Such a result would manifestly be contrary to the remedial purposes of this proposed legislation. On the other hand, if the corporations excluded from Section 74 were merely those in the limited sense, and the corporations included under Section 75 were those in the broad sense, the intermediate group of associations referred to could resort to either of these sections for debtor relief. However, no rational purpose would be served by permitting limited partnerships, partnership associations, unincorporated companies, joint stock companies, Massachusetts or common law trusts, and similar groups to choose

36. "Section 74. Compositions and Extensions.-a. Any person excepting a corporation may file a petition, or, in an involuntary proceeding before adjudication, an answer within the time limited by Section I8 (b) of this Act, ... stating that he is insolvent or unable to meet his debts as they mature, and that he desires to effect a composition or an extension of time to pay his debts." In a later draft of this Bill, introduced in the Senate by Senator Hastings [Calendar No. I310; see SEN. REP. No. 1215, 72d Cong., 2d Sess., Ser. No. 9647 (I933) ], the opening clause was amended to read "any person except a corporation and any person except a farmer may file a petition. . . ." However, in a subsequent draft, and as finally passed, the original language first above quoted was restored.

37. The early drafts of this subdivision specifically included "drainage, irrigation, levee, sewer, and paving improvement districts" (H. R. 14359); and the companion bill in the Senate (S. 555I) also included "any railroad not engaged in interstate commerce except a street, suburban, or interurban railway which is not operated as a part of a general system of railroad transportation." However, all of these special provisions were dropped in a later bill, H. R. 5884 , introduced in the $73 \mathrm{~d}$ Congress. See infra note 46.

38. The preamble, which contained the repealing clause, read as follows: ". . . and it is hereby amended by repealing sections $\mathrm{I2}$ and $\mathrm{I3}$ thereof. . .

39. Pampanga Sugar Mills v. Trinidad, 279 U. S. 2rI (I929). 
between "composition or extension" relief and "reorganization" relief, and at the same time denying a similar choice to stock corporations.

The reports of the Judiciary Committees ${ }^{40}$ and the debates in Congress ${ }^{41}$ fail to shed any light on the specific intention of the draftsmen of H. R. I4359. The substitution in this measure of the language, "any corporation which could become a bankrupt under Section 4", for the Hastings phrase, "any moneyed, business or commercial corporation, except a municipal, railroad, insurance or banking corporation",42 may have been made merely for the sake of improving the phraseology without any intent to change the original concept, or it may have had a larger and more substantive purpose. However, if Sections 74 and 75 had been enacted in the form originally proposed in $\mathrm{H}$. R. I4359, there can be little doubt that the courts would have given to the term "corporation" the broad meaning imported by the definition of the Bankruptcy Act. In view of the change in language, it would hardly have been assumed that its sole purpose was to simplify phrasing; it would rather have been presumed that the change was intended for the more substantial and rational purpose of bringing within the scope of the reorganization section all corporations which could become bankrupt under Section 4.

When $H$. R. 14359 was finally passed, ${ }^{43}$ the corporate reorganization section was dropped; ${ }^{44}$ and when it was discovered that by reason of the repeal of Section I2 corporations were excluded from any form of debtor relief under the Act, a concurrent resolution ${ }^{45}$ was promptly adopted, deleting the repealing clause and restoring Section $\mathrm{I} 2$, thus making the latter section available, to the same extent as theretofore, to corporations. In the next Congress, a separate measure providing for corporate reorganizations, and retaining substantially the form and language of Section 75 of $H$. R. 14359, was introduced. ${ }^{40}$ This measure, without Committee hearings or extended debate in Congress, was passed with a few minor changes, and

40. Supra note I2.

4I. Supra note 35 .

42. Supra note 32 .

43. On March 3, I933.

44. The corporate reorganization section was the subject of considerable controversy, and was deleted because of the desire to enact the relief legislation in respect to debtors, farmers and railroads. In this connection see SEN. Rep. No. I215, 72d Cong., 2d Sess., Ser. No. 9647 (1933) ; 76 Cong. Rec. 4876 (r933) ; 77 Cong. Rec. 5013 (1933).

45. S. Con. Res. 45, 72d Cong., ad Sess. (I933), submitted by Senator Hastings, was adopted by both Houses on March I, 1933. 76 CoNG. REC. 5347 (I933).

46. H. R. 5009 was offered by Representative McKeown on April I4, I933 (73d Cong., Ist Sess.). This was followed by H. R. 5884, also introduced by Representative McKeown, and passed by the House on June 5, I933. 77 CoNG. Rec. 4884, 5015 (I933). The later bill was offered in the Senate on June 6, I933, and referred to the Committee on Judiciary. 77 Cong. Rec. 5060 (I933). For full text of H. R. 5884, see 77 Cong. REc. 5009-5013 (I933); H. R. REP. No. I94, 73d Cong., Ist Sess., Ser. No. 9774 (I933). There was considerable pressure on the part of many corporations for statutory reorganization relief under the Bankruptcy Act. 77 CoNG. Rec. 5013 (1933). 
became the present Section $77 B .^{47}$ It is to be noted that there was no return to the original intention of repealing Section I2. ${ }^{48}$ Thus the corporations amenable to Section $77 B$ still have the alternative of resort to a composition proceeding under Section I2.

As has been pointed out, if Section 74 and Section 77 B had been enacted concurrently, the conclusion would be fairly inevitable that the term "corporation" in both instances would necessarily be given the broadest construction; but since the two sections were enacted at different times, this conclusion no longer follows. Section 74 in itself contains nothing which would conflict with the broad construction; and it has therefore been assumed that all corporations in the sense of the bankruptcy definition are excluded from its purview. ${ }^{49}$ If Section $77 B$, when enacted, had incorporated a repeal of Section 12 , it could still be argued most forcibly that the scope of the Section included all corporations in the bankruptcy sense; for if such corporations were excluded from Section 74, and not all of them were comprehended within Section $77 \mathrm{~B}$, the intermediate groups would, as above indicated, find no debtor relief under the Act. However, Section I 2 was not repealed, and this argument likewise falls.

Therefore the study of the origin and history of Section $77 \mathrm{~B}$ as thus far developed is of little aid in the solution of our problem. The only argument that can be derived from this study is the one already made, namely, that the change of language in the corporate reorganization section was presumably intended for the more logical purpose of expanding the meaning of the term "corporation." However, this argument, though rational, is not realistic. The primary source of the succession of measures dealing with corporate reorganizations and culminating in Section $77 \mathrm{~B}$ was the familiar equity reorganization proceeding. The purpose of all these measures was to procure for such a reorganization the advantage, lacking in

47. In the Senate this measure was referred to the Committee on Judiciary. 77 Cong. REC. 506I (1933). The Bill was revised and, with amendments, appeared in the Senate on March 15, I934, accompanied by the Report of Senator Van Nuys. SEN. REP. No. 482, 73d Cong., 2d Sess., Ser. No. 9769 (I934) ; 78 CoNG. REC. 4566 (I934). Later, on the floor of the Senate, Senator Van Nuys outlined the provisions of the Bill, and during the course of debate, the Senate adopted severat amendments. 78 CoNG. REc. 7804,7885 et seq., 7897 et seq. (I934). The Bill was passed by the Senate on May 4, I934: 78 Cong. REc. 8082, 8I5I (1934). Later the Bill went back to conference [78 CoNG. REc. 8I5I, 835I (1934)], and on May 24, 1934, was reported to the House, accompanied by Conference Report I773. 78 CoNG. REc. 9547 (1934). It was agreed to by the House, as amended, on May 29, I934. 78 ConG. REc. 9899 (1934). The Senate approved the Conference Report on June $x, 1934$ [78 Cong. REc. IO209 (1934) ], and the measure was signed by the President on June 7, 1934. For further details of the history of the Bill, see Friendly, Some Comments on the Corporate Reorganizations Act (I934) 48 HARv. L. REv. 39, 49; Sunderland, A Brief Sketch of the Historical Backgrount and of the Events Leading up to the Enactment of the New Corporate Bankruptcy Reorganization Act (1934) I Corp. Reorg. 4, 46; PAYNe, PLANS OF Corporate REORGANIZATION (1934) 35-37.

48. Supra note 29.

49. McKeown and Langeruttig, Federal Debtor Retref Laws (I935) i8; C. C. H. BankRUPTCy LAw Service (New ed.) 6т6; Weinstein, Chapter VIII of the Bankruptcy Act (I933) 38 CoMrM. L. J. I7I. 
the equity court but permitted in the bankruptcy court, of the control of minorities by majorities. Beyond this single advantage, all the new features of Section $77 \mathrm{~B}$ could readily have been supplied by direct Congressional legislation on the subject, without recourse to the Bankruptcy Act. The equity reorganization, in which Section $77 B$ had its origin, was virtually limited to business corporations. It is thus understandable why the general framework of Section $77 \mathrm{~B}$ appears to contemplate only stock corporations. It has been stated by former Representative McKeown, who introduced and sponsored several of the measures on corporate reorganization, that the term "corporation" was used in the broad bankruptcy sense; ${ }^{50}$ but nevertheless it is to be doubted whether the actual draftsmen of these measures gave any thought to the question. It is more probable that they were thinking entirely in terms of stock corporations, and that in substituting the later language for the earlier, they had in mind merely the idea of improving or simplifying phraseology.

While for the purposes of discussion it may be interesting to consider the evolution of Section $77 B$, it must nevertheless be recognized that the courts are hardly likely to resort to historical considerations in construing the term "corporation." The evolution of a statute, the annotations and comments of its framers, and the legislative debates preceding its passage, are taken into account only when the language of the statute is itself ambiguous or obscure. ${ }^{51}$ Where that language is not ambiguous, and where it can be applied to a particular situation, the courts have commonly so applied it even though contrary to the known intention of the legislature. ${ }^{52}$ Therefore, whatever may have been the actual intention of the draftsmen of Section $77 \mathrm{~B}$, since the language of the text is unequivocal, such intention must be disregarded by the courts.

50. Loc. cit. supra note I4.

51. See Duplex Printing Press Co. v. Deering, 254 U. S. 443, 474 (I92I) ; cf. Pennsylvania R. R. v. International Coal Mining Co., 230 U. S. I84 (I913) (debates); Lapina v. Williams, 232 U. S. 78 (I9I4) (reports of legislative committees); United States v. Missouri Pac. R. R., 278 U. S. 269 (I929) (legislative history); Railroad Comm. v. Chicago, Burlington \& Quincy R. R., 257 U. S. 563 (1922).

52. Knickerbocker Ice Co. v. Stewart, 253 U. S. I49 (I920); United States v. Chicago \& N. W. R. R., I57 Fed. 616 (D. Neb. I907) ; In re Murphy, 23 N. J. L. I80 (I85I). Familiar examples of this rule of interpretation are found in the construction of the White Slave Traffic Act, 36 STAT. 825 (I9I0), I\& U. S. C. A. $\$ \$ 397-404$ (I927), and of the Act against Using Mails to Promote Frauds, 35 Stat. Ir3o (I909), r\& U. S. C. A. \& 338 (I927), amending 25 Stat. 873 ( 1889 ). The former statute has been applied to a single act of private immorality, even though it was conceded that the statute was directed against general commercialized vice. Caminetti v. United States, 242 U. S. 470 (IgI7). Under the other statute, though undoubtedly intended to prevent the use of the mail in general schemes to defraud the public [Durland v. United States, I6I U. S. 306, 314 (I896)], it has been repeatedly held that the language was applicable to the mailing of a false financial statement for the specific purpose of obtaining credit. Scheinberg v. United States, 213 Fed. 757 (C. C. A. 2d, I9I4); Bettman v. United States, 224 Fed. 819 (C. C. A. 6th, I9I5), cert. denied, 239 U. S. 642 (I915) ; Kaplan v. United States, 229 Fed. 389 (C. C. A. 2d, IgI6); United States v. Ball, 294 Fed. 750 (M. D. Pa. I924). 


\section{Policy}

Were the language of this provision not entirely clear and unequivocal, the courts in construing its meaning would no doubt take into account the considerations of public policy. ${ }^{53}$ Section $77 \mathrm{~B}$ combines as its principal feature the readjustment of secured indebtedness, which is permitted in equity but not in a bankruptcy composition, with the control of minorities by majorities, which conversely is permitted in bankruptcy but not in equity. This particular feature of relief may be just as necessary to the various bodies comprised within the broad definition of "corporations" as to corporations in the restricted sense, and to non-profit organizations as to business associations. Public policy, therefore, supports an extension of the benefits of the Section to its farthest reasonable limits. Indeed, in the case of non-profit bodies, such policy would seem particularly strong. A reorganization is essentially a constructive proceeding; it has for its object the continued existence of an enterprise, as contrasted with a bankruptcy proceeding, which normally results in a termination of the enterprise. It is hardly good policy so to interpret the Bankruptcy Act that a religious, educational, fraternal or charitable institution shall be permitted to be adjudged bankrupt, and thus have its beneficial activities ended, but be denied the right to reorganize and thus preserve its existence. From the aspect of the public welfare, it may be more vital to insure the continuance of such an institution than to maintain the existence of a private business enterprise. The purpose of Section $77 \mathrm{~B}$ is remedial; and remedial legislation should be broadly and liberally construed. ${ }^{54}$

\section{Context}

Only one strictly legal argument can be advanced against the natural construction of the phrase, "any corporation which could become a bankrupt under Section 4 of this Act." The definition section of the Bankruptcy Act provides generally that the words and phrases therein recited are to be construed as defined, "unless the same be inconsistent with the context"; and subdivision $k$ of Section $7 \mathrm{~B}$ provides that "all other provisions of this Act, except such as are inconsistent with the provisions of this Section $77 \mathrm{~B}$, shall apply to proceedings instituted under this Section." 56 The contention may thus be made that the general context of Section $77 \mathrm{~B}$ imports a nar-

53. Di Biase v. Garnsey, I03 Conn. 2I, I30 Atl. 8I (1925) ; Conover v. Public Service Ry., 80 N. J. L. 681, 78 At1. I87 (I910) ; Carey v. Cruise, 246 N. Y. 237, 158 N. E. 3I5 (1927).

54. "It should at all times be borne in mind that the act is remedial, and must be liberally construed with a view of carrying into effect its obvious purposes and intent." I CoLLIER, BANRRuprcy (I3th ed. 1924) 4. See to same effect, Botts v. Hammond, 99 Fed. 9 I6 (C. C.

A. 4th, I900) ; I ReMrngton, B.ANkRUPTCY (4th ed. I934) 57.

55. For text, see supra note 15 .

56. Supra note 17. 
rower meaning of the term "corporation" than does the definition of Section I (6)..$^{57}$

Such a contention, however, is not tenable. It is true that the Section throughout speaks of stockholders and stock; but it must nevertheless be borne in mind that primarily the Section deals with the readjustment of debts, and only incidentally with the interests of stockholders. Under the Section, it is mandatory that the plan shall modify or alter the rights of creditors, but only optional that it shall modify or alter the rights of stockholders. ${ }^{58}$ It is manifest that the provisions relating to the readjustment of debts are as applicable and as likely to be necessary to membership corporations as to stock corporations, and to unincorporated bodies as to bodies corporate.

By interpretation, furthermore, the provisions relating to stockholders may readily be adapted to the members of partnership associations, unincorporated companies, joint stock companies, Massachusetts trusts and like bodies, whose interests are analogous to those of stockholders. ${ }^{59}$ In specific cases, where particular provisions are not applicable, those provisions may be disregarded. In any event, and under any construction, there would necessarily be numerous cases in which certain provisions of the Section would not apply. For example, where the corporation is insolvent or where the plan deals only with the readjustment of debts, the provisions relating to stockholders, even in the case of stock corporations, would be inoperative. Thus there is no inherent difficulty in disregarding certain provisions of the Section where they do not apply, and in taking advantage merely of such provisions as are applicable to a specific case. There are many instances of statutes which, while drafted for specific purposes, have been phrased in language sufficiently broad to permit of application to analogous or related situations; and in such instances, the courts have consistently extended the application of the statute. ${ }^{60}$

Accordingly, from the aspects of natural meaning, of public policy, and perhaps of historical evolution, the term "corporation", as used in Section $77 \mathrm{~B}$, should be construed in the broad sense of the bankruptcy definition.

57. Statutory language is to be construed in the light of context and in harmony with the statute as a whole. Nashville, Chattanooga \& St. Louis Ry. v. Tennessee, 262 U. S. 3 I8 (I923) ; United States v. Baltimore \& O. S. W. R. R., I59 Fed. 33 (C. C. A. 6th, Ig08); Oglesby Coal Co. v. Commissioner of Internal Revenue, 46 F. (2d) 6r7 (C. C. A. 7th, I93I).

58. § 77B (b), 48 SтAт. 9I3, iт U. S. C. A. \$207 (b) (Supp. I934): "A plan of reorganization within the meaning of this section (I) shall include provisions modifying or altering the rights of creditors ; $:$ (2) may include provisions modifying or altering the rights of stockholders . . ." (italics supplied).

59. Cf. Bryan v. Welsh, 72 F. (2d) 6I8 (C. C. A. Ioth, I934), where it was declared "to be the well-settled rule that certificate holders in a common-law trust stand in their relation to the trust as stockholders in a corporation."

6o. Supra note 52. 


\section{Distinction Between Voluntary and Involuntary Proceedings}

The question may arise whether any distinction is to be made, in respect to corporations amenable to Section $77 \mathrm{~B}$, between a voluntary and an involuntary proceeding for reorganization. The Section permits creditors to file a petition against "any corporation", subject to the limitations that the corporation shall not have previously filed a petition or answer in its own behalf under the Section, and that the petition must be filed "with the court in which such corporation might file a petition under this Section." ${ }^{11}$ The phrase "any corporation" by itself is, of course, extremely broad, and would comprise all the bodies covered by the definition of Section I (6) of the Act. This definition includes railroad, banking and insurance corporations, and building and loan associations, ${ }^{62}$, although such corporations are excluded from the provisions of Section $4 .{ }^{63}$ Since the phrase "any corporation" is not restricted by the qualification employed earlier in the subdivision with reference to voluntary applications for reorganization, ${ }^{64}$ it may perhaps be argued that for the purposes of an involuntary proceeding by creditors the term is broader than in the case of a voluntary proceeding by a debtor. However, there is little likelihood that the courts will permit an involuntary proceeding to be instituted against a debtor which would not be permitted to file a voluntary proceeding. No purpose would be served by allowing creditors a wider latitude than is given to the debtor itself. Indeed, the general policy of the Bankruptcy Act is the converse. Under Section 4, as already indicated, there are several classes of debtors who may file a voluntary petition in bankruptcy, but who canrot be subjected to an involuntary proceeding. Subdivision $a$ of Section $77 \mathrm{~B}$, when read as a whole, clearly manifests a purpose to confine a reorganization proceeding to the corporations there specified. Even though the term "corporation", in the case of a creditors' proceeding, is not qualified by restrictive language, the courts should have no difficulty in reading into the provision under consideration the same limitation as applies to a voluntary proceeding by a debtor.

6I. \$77B (a), 48 STAT. 9I2, II U. S. C. A. §207 (a) (Supp. 1934): "Three or more creditors who have provable claims against any corporation which amount in the aggregate, in excess of the value of securities held by them, if any, to \$rooo or over may, if such corporation has not filed a petition or answer under this section, file with the court in which such corporation might file a petition under this section, a petition stating that such corporation is insolvent or unable to meet its debts as they mature and, if a prior proceeding in bankruptcy or equity receivership is not pending, that it has committed an act of bankruptcy within four months, that such creditors propose that it shall effect a reorganization."

62. The definition would obviously not include municipal corporations. See I Collier, BANKRUPTCY (I3th ed. Ig24) 2 II.

63. For text of Section 4, see supra note 19.

64. I. $e$., the requirement that the association be one which could become a bankrupt under the Act, or any railroad or other transportation corporation, except a railroad corporation amenable to Section 77. For full text of this provision, see supra note I8. 


\section{Analogy of Section 4}

There is still a further problem arising by reason of the differentiation in Section 4 between voluntary and involuntary petitions in bankruptcy. A voluntary proceeding may be instituted by any corporation of the kind included within the definition of the Act, except as specified in Section 4 (a). An involuntary proceeding, on the other hand, is limited to unincorporated companies and moneyed, business or commercial corporations, except as specified in Section 4 (b). ${ }^{65}$ If this differentiation is to be carried over, by implication, into Section $77 \mathrm{~B}$, the fact that a voluntary proceeding for reorganization is available to corporations in the broader sense, may not necessarily subject all such corporations to an involuntary proceeding. By analogy to Section 4 (b), it may be argued that an involuntary proceeding under Section $77 \mathrm{~B}$ should be similarly limited to unincorporated companies and moneyed, business or commercial corporations. It may further be argued that since the text of Section $77 \mathrm{~B}$ does not use the phrase "unincorporated company", but merely the term "corporation", an involuntary proceeding under this Section should be still further restricted, namely, to a moneyed, business or commercial corporation. These arguments find support in the doubt that may well be cast upon the general policy of permitting creditors to force a reorganization upon an unwilling debtor. It is true, of course, that Congress has by express provision permitted an involuntary reorganization; but it may still be argued that the provision should be restricted to its narrowest possible limits. Against such implied restriction, however, there are several countervailing considerations. In the absence of any expressly restrictive language in Section $77 \mathrm{~B}$, it is difficult to see how a court can invoke, merely by implication, the analogy of Section 4. In addition, the principle that remedial legislation should be liberally construed, and the policy favoring the extension of the benefits of reorganization to corporations in the broadest sense, apply to involuntary as well as voluntary proceedings. In view of these various considerations, it is not likely that the courts will limit the scope of the term in respect to an involuntary reorganization.

\section{Railroad or Other Transportation Corporation A. Railroad Corporation}

Subdivision $a$ of Section $77 \mathrm{~B}$ permits a reorganization proceeding to be instituted not only by any corporation which could become a bankrupt under Section 4 of the Act, but also by "any railroad or other transportation corporation, except a railroad corporation authorized to file a petition or answer under the provisions of Section 77 of this Act . . ." 66 Subdivision $r$ of Section 77 defines the term "railroad corporation", and specifically 
makes the definition applicable "wherever the term is used in the Act." 67 By "Act", of course, is meant the Bankruptcy Act as a whole, and not merely Section 77.68 The definition reads as follows:

"The term 'railroad corporation' as used in this Act means any common carrier by railroad engaged in the transportation of persons or property in interstate commerce, except a street, suburban, or interurban electric railway which is not operated as a part of a general railroad system of transportation or which does not derive more than 50 per centum of its operating revenues from the transportation of freight in standard steam railroad freight equipment."

Section 4 of the Act excepts railroad corporations from the purview of bankruptcy. ${ }^{69}$ Prior to the adoption of Section 77 , it was never questioned that the term "railroad corporation", as used in Section 4, comprised intrastate as well as interstate railroads. ${ }^{70}$ In respect to street railways, the decisions have been in conflict. ${ }^{71}$ However, in view of the definition of

67. 47 STat. 4474 (I933), II U. S. C. A. \$ 205 (Supp. I934).

68. "This Act" in an amended section of a statute ordinarily refers to the original as well as to the amending act. State ex rel. Griffith v. Anderson, IIy Kan. 540, 232 Pac. 238 (I925); 5o C. J. 1094, n. 98 (1932).

69. For text, see supra note I9.

70. The National Bankruptcy Act of I867, I4 STAT. 5I7 (I867), provided in \$ 37 for the voluntary or involuntary bankruptcy of "all moneyed business or commercial corporations"; and under this broad language, it was held that railroads could be adjudged bankrupts. Adams v. Boston, H. \& E. R. R., I Fed. Cas. No. 47 (D. Mass. 1874) ; Winter v. Iowa, M. \& N. P. Ry., 30 Fed. Cas. No. I7,890 (D. Iowa I873); In re California Pac. R. R., 4 Fed. Cas. No. 2,315 (D. Cal. I874). The Bankruptcy Act of I8g8, as originally adopted, discarded this language. Under Section 4 (a), which related to voluntary bankruptcy, corporations were excluded; and under 4 (b), which related to involuntary bankruptcy, only certain corporations, to wit, those "principally engaged in manufacturing, trading, printing, publishing, or mercantile pursuits", were permitted to be adjudged bankrupt. Obviously, neither of these subdivisions comprehended railroads. By the Ray Amendment of I903, 32 STAT. 797 (1903), mining corporations were added. However, by the amendment of IgI0, 36 STAT. 839 (I9ro), II U. S. C. A. $\$ 22$ (I927), the scope of Section 4 in respect to corporations was considerably extended. Under subdivision $a$, all corporations, except municipal, railroad, insurance or banking corporations, were permitted to file voluntary petitions; and under subdivision $b$, the language of the Act of I867 above quoted was restored, though with the same exceptions as recited in subdivision $a$. For these various changes in Section 4 , see I ColIIER, BANKRUPTCY (I3th ed. I924) I9x; for discussion, see I id. at I96, 2 I I I REMINGTON, BANKRUPTCY (4th ed. I934) IO6, I59 et seq. Thus even under the broadened scope of the IgIo amendment, railroads were still excluded. There is no case which specifically discusses the question whether the term "railroads" referred to interstate or intrastate lines. It seems to have been assumed to cover both. Columbia Ry., Gas \& Electric Co. v. South Carolina, 27 F. (2d) 52, 55 (C. C. A. 4th, Ig28): "It is true that the general designation of railroads contemplates an extended system sometimes covering an entire state, and not infrequently several states."

By virtue of the definition of "railroad corporation" in Section 77 , it would seem, as pointed out in the text, that intrastate railroads are now amenable to bankruptcy, both voluntary and involuntary.

7I. Cf. In re Grafton Gas \& Elec. Light Co., 253 Fed. 668 (N. D. W. Va. IgI8) (a purely local electric street railway operating a short line over the streets of a single town is not a "railroad" within Section 4 (a) of the Bankruptcy Act), with In re Columbia Ry., Gas not a "railroad" within Section 4 (a) Of the Ban), af'd, 27 F.' (2d) 52 (C. C. A. 4th, Ig28) (a street railway with twenty miles of urban and suburban lines is a "railroad corporation" within Section 4 of the Bankruptcy Act, and not subject to adjudication as a bankrupt. See also (I928) 38 YALE L. J. 256. 
"railroad corporations" furnished by Section 77, it is clear that the railroads now excepted from the operation of Section 4 are interstate railroads and electric railways which are operated as part of a general railroad system of transportation and which derive more than fifty per cent. of their operating revenues from the transportation of freight in standard steam railroad equipment. $^{72}$ This effect upon Section 4 was specifically intended. ${ }^{73}$

From the reference in Section $77 \mathrm{~B}$ to the provisions of Section 4 , it follows necessarily that any railroad corporation, with the exception of an interstate railroad or electric railway amenable to Section 77 , may be the subject of a reorganization proceeding. It therefore appears from the foregoing discussion that the provision in subdivision $a$ of Section $77 \mathrm{~B}$, "any railroad . . . corporation except a railroad corporation authorized to file a petition or answer under the provisions of Section 77 of this Act", is rendered entirely superfluous and might have been omitted.

\section{B. Or Other Transportation Corporation}

It has never been questioned that transportation corporations other than railroads could be adjudged bankrupt. ${ }^{74}$ Thus steamship, aeroplane, canal and express associations, and associations operating bus, auto, truck, and pipe lines, and the like, whether engaged in interstate or intrastate commerce, are entitled to the benefits of the Act and subject to its provisions. This class of corporations is, therefore, covered by the provision, "which could become a bankrupt under Section 4 of this Act", and the reference to "other transportation corporation" is superfluous. ${ }^{75}$

72. The double requirement does not seem to have been contemplated. Apparently, it was the design of the author of the provision, that Section 4 , and therefore Section $77 \mathrm{~B}$, should exclude street railways which either were part of a general railroad system or derived their operating revenue chiefly from freight transportation. See third paragraph of letter of Feb. 2, 1933, cited infra note 73. A careful analysis of the language actually used in the provision, however, will support the conclusion set forth in the text.

73. See letters of American Transit Ass'n (C. D. Cass, General Counsel) to Senator Hastings, dated Feb. $x$ and 2, I933, pp. 91 and 105 of Senate Committee Print, 72d Cong., 2d Sess. (1933), Criticisms and Snggestions Relating to $H$. R. 14359 and S. 555I, Amending the Bankruptcy Act. See also McKeown and Langeluttig, Federal Debtor Retref Laws (1935) I4I, I42: "These provisions" (referring to subdivision n) "were placed in the Act with particular view to the subway situation in New York City. The intent was to deny application of the Corporate Reorganization section to utilities not only owned by the city, as the latest subway constructed in New York, but also to those operated under contract with the city, like the Interborough Rapid Transit in New York City.

"The Act contains a proviso, however, that if not more than 20 per cent. of the operating revenue of a company is derived from municipal operation, then the company may have the advantages of the Corporate Reorganization section. This proviso was inserted, having in particular view the situation in Philadelphia, where the street railways are privately owned. There is, however, one small spur which was constructed and is owned by the City of Philadelphia, but is leased to the private company which runs the rest of the city railways. The proviso was intended to permit companies in the condition of the Philadelphia company to take advantage of the Act in spite of the small amount of municipally owned railways in their system."

74. I REMINGTON, BANKRUPTCY (4th ed. I934) I63.

75. For text, see supra note I8. 


\section{V. "And Except as Hereinafter Provided"}

This further exception refers to subdivision $n$ of Section 77B. ${ }^{76}$ The language of the subdivision is exceedingly involved and obscure. However, its import may be sensed from a knowledge of its general purpose. As far as it is possible to paraphrase the subdivision, it would seem to mean that the Section shall not be construed to apply to any corporation owning or operating a railroad or railway wherein a municipality has any interest, as owner or co-owner, operator or co-operator, or beneficiary under any contract, lease, certificate or other lawful operating arrangement, unless such corporation derives no more than twenty per cent. of its operating revenue from such operations.

It will be recalled that in order to reorganize under Section 77 a street, suburban or interurban electric railway must be a part of a general railroad transportation system and be engaged chiefly in the transportation of freight. These two requirements no doubt will bar from the benefits of that Section a large majority of such railways. Normally, however, these railways would be amenable to Section $77 B$ except for subdivision $n$ thereof. Since many of such railways are operated today under arrangements with municipalities and derive more than twenty per cent. of their operating revenue from such operation, it is obvious that they would also be excluded from the benefits of reorganization under Section 77B. It is clear, therefore, that in such cases these railways are excluded both from Section 77 and from Section $77 \mathrm{~B}$, and for the purpose of reorganization are still relegated to the equity courts. It should be observed, however, that despite subdivision $n$, which is restricted to Section $77 \mathrm{~B}$, these railways may nevertheless become bankrupt under Section 4 of the Act and entitled to composition relief under Section $12 .{ }^{77}$

\section{VI. "Present Operations"}

Any corporation falling within the categories specified in subdivision $a$ of Section $77 \mathrm{~B}$, may file an original petition, or an answer before adjudication in an involuntary proceeding in bankruptcy, or a petition "in any proceeding pending in bankruptcy, whether filed before or after this section becomes effective, provided the present operations of such corporation do not exclude it hereunder, and whether or not the corporation has been adjudi-

76. 48 Stat. 922, II U. S. C. A. \$ 207 (n) (Supp. I934) : Nothing contained in this section shall be construed or be deemed to affect or apply to the stockholders, creditors, or officers of any corporation operating or owning a railroad or railroads, railway or railways, owned in whole or in part by any municipality and/or owned or operated by a municipality, or under any contract to any municipality by or on its behalf or in conjunction with such municipality under any contract, lease, agreement, certificate, or in any other manner provided by law for such operation: Provided, however, That this paragraph shall not apply to or affect any corporation or the stockholders, creditors, or officers thereof, if not more than 20 per centum of its operating revenue is derived from such operations."

77. Supra note 29. 
cated a bankrupt." 78 From the foregoing context, it appears that the "present operations" proviso can relate only to the case of a voluntary petition for reorganization filed in a pending bankruptcy proceeding. ${ }^{79}$ It would also seem clear that the provision is restrictive and not expansive; as it reads, its purpose is to exclude corporations which otherwise would be amenable to Section $77 \mathrm{~B}^{80}$

It has been asserted, however, that the provision was intended to apply to any reorganization proceeding, whether by way of an original petition or in a pending bankruptcy, and was specifically inserted to enlarge the scope of Section $77 \mathrm{~B}$ by permitting the reorganization of insolvent insurance and banking corporations, and building and loan associations, which are not in active operation. ${ }^{81}$ Nevertheless, this purpose, which might very readily have been expressed in apt and unequivocal language, has very definitely failed of accomplishment. ${ }^{82}$ Since the proviso cannot possibly be applied otherwise than to the case where the corporation is already in bankruptcy, the only construction that can be adopted is that it excludes certain corporations which could be adjudicated bankrupt but which may not be reorganized under this Section. The only situation in which this may occur is that where the corporation has changed the nature of its business operations between the time it became subject to a bankruptcy proceeding and the time of the filing of a petition for reorganization. Such a situation, though likely to occur only rarely, is nevertheless conceivable. Thus a company authorized to engage in two such enterprises as mining and railroad transportation, but conducting at the time primarily a mining business, may become the subject of bankruptcy, and subsequently change its business so that it is predominantly that of railroad transportation $;^{83}$ or an intrastate railway may subsequently become interstate in character; or a street railway, by virtue of an arrangement with a municipality, may subsequently fall within the prohibition of subdivision $n .^{84}$ In these or analogous cases, the "present operations" proviso, which no doubt refers to the time of the filing of the reorganization proceeding, would seem to exclude such a corporation from the

78. For full text, see supra note 18.

79. In re New York Title \& Mtg. Co., 9 F. Supp. 319 (N. D. N. Y. 1934).

80. Id. at 328 .

8i See McKeown and Langeluttig, Federal Debtor Relief Laws (I935) IOg-II1: "However, when a bank, insurance company, or a building and loan association ceases operations . . . the benefits of section $77 \mathrm{~B}$ should be extended to them for the purposes of possible resuscitation. The provisions regarding present operations were inserted with that purpose in view at the earnest solicitation before the Conference Committee of persons interested in the reorganization of such corporations then in difficulties." This intention was considered in the case of In re New York Title \& Mtg. Co., 9 F. Supp. 3rg (N. D. N. Y. 1934), and was disregarded.

82. In re National Surety Co., 7 F. Supp. 959 (N. D. N. Y. I934) ; In re Union Guarantee \& Mtg. Co., 8 F. Supp. 28I (S. D. N. Y. I934); In re New York Title \& Mtg. Co., 9 F. Supp. 319 (N. D. N. Y. I934) ; In re Peoria Life Ins. Co., C. C. H., Bankruptcy LAw SERVICE (New ed.) I306 (C. C. A. 7th, I935).

83. Cf. In re C. Jutte \& Co., 266 Fed. 357 (C. C. A. 3d, I920).

84. Supra note 76 . 
benefits of Section $77 \mathrm{~B}$, even though the corporation was in bankruptcy. Seldom as such a situation might occur, yet if it should arise, the courts would undoubtedly be obliged to exclude the debtor from the benefits of Section $77 \mathrm{~B}$. Though there is clearly no rational reason to permit a corporation to be liquidated in bankruptcy and yet to deny it the privilege of reorganization, nevertheless such a result, under the language of the proviso and its contextual position, would seem unavoidable. Beyond this rare case, it seems impossible to give any other effect to the proviso.

\section{Subsidiary Corporations}

Subdivision $a$ of Section $77 B$ also provides that "any corporation the majority of the capital stock of which having the power to vote for the election of directors is owned, either directly or indirectly through an intervening medium, by any debtor, or substantially all of whose properties are operated by such debtor, under lease or operating agreement, may file, with the court in which such debtor had filed its petition or answer, and in the same proceeding, a petition stating that it is insolvent or unable to meet its debts as they mature and that it desires to effect a plan of reorganization in connection with, or as a part of, the plan of reorganization of such other debtor."

It is to be noted that the term "any corporation" as here used is not qualified by the language, "which could become a bankrupt under Section 4 of this Act", or by any other restrictive language, except such as pertains to the subsidiary relationship. The question that first arises, therefore, is whether the word "corporation", with respect to a subsidiary, includes all the bodies comprehended within the limits of the definition of Section I (6), or whether the word, as here used, is restricted to stock corporations. The descriptive language following the phrase "any corporation" divides subsidiaries into two classes: those which are subsidiaries by virtue of stock ownership, and those which are subsidiaries by virtue of operation of properties. As to the first class, it would seem quite clear that only stock corporations can possibly be meant. There may perhaps be rare cases in which a debtor corporation is a member of a partnership association, common law trust or like body, owning a majority interest, and controlling such body as a subsidiary. Theoretically, therefore, it might be argued that such ownership and control, by analogy to stock control, are intended to be comprehended within the compass of the phrase "majority of capital stock of which having power to vote for the election of directors." Such an argument, however, is obviously strained; the language of the phrase is so specific that it is exceedingly difficult to apply it to such a body. It may more plausibly be applied to a joint stock company. Nevertheless, it would appear quite clear that with respect to subsidiaries falling within the first category, it must be held that Congress had in mind stock corporations in the strict sense. 
With respect to the second group, that is, subsidiaries substantially all of the properties of which are operated by the principal debtor, the possible scope is obviously much broader. A debtor may readily operate substantially all of the properties of a limited partnership, partnership association, unincorporated company, joint stock company, common-law trust, or virtually any of the enterprises included by the term "corporation" as defined in Section I (6). In this group, therefore, the phrase "any corporation" would seem to possess no inherent restriction.

It is difficult to conceive, however, that Congress, in speaking of subsidiaries, intended a limited meaning in one category, and an unrestricted meaning in another. It is much more plausible to argue that in both cases, Congress had in contemplation only such subsidiaries as were stock corporations. Though the same policy, already discussed, which favors the broad construction of the term "corporation" in the case of the principal debtor applies equally to the case of a subsidiary, the language with respect to subsidiaries appears to be too specific to permit of enlargement by interpretation.

It may be observed, incidentally, that the descriptive language pertaining to subsidiaries opens of itself a wide field of speculation as to the circumstances, in particular cases, under which one corporation may be deemed a subsidiary of another. However, it is not within the purpose of this discussion to treat that subject.

Even on the assumption that a subsidiary must be a stock corporation, there is still a problem as to whether the restrictive qualifications of subdivision $a$ pertaining to the principal debtor are to be implied in the case of a subsidiary. In order to reorganize under Section $77 \mathrm{~B}$, the principal debtor must be a corporation which could become a bankrupt under Section 4, or a railroad or railway corporation which is excluded from the purview of Section 77. However, there is no such express restriction in the case of a subsidiary; and it is quite possible that Congress, having in mind the desirability of a comprehensive reorganization of the parent corporation in conjunction with all of its subsidiaries, may have omitted the restriction designedly. In the case of a large enterprise, it is not uncommon for the company to organize or acquire subsidiaries for the purpose of banking, insurance, or railroad transportation; and it is also conceivable that such an enterprise, if paternalistically inclined, may organize a building and loan association. In the absence of express restriction, and in the light of public policy, though the term "corporation", with respect to subsidiaries, would appear limited, as pointed out, to stock corporations, it may be strongly argued that the term should be extended to as broad a boundary as the language permits, and thus to include within its purview banking, insurance and railroad corporations-except, of course, such railroads and railways as are excluded by subdivision $n$. Yet in view of the general purpose of 
Section $77 B$, which is clearly to limit the privilege of reorganization to such corporations as can become bankrupt under Section 4, it would seem more logical to imply a similar limitation in the case of subsidiaries; and it is therefore likely that the courts will supply such a restrictive qualification by implication.

\section{Corporation Under Prior Receivership}

Subdivision $i$ of Section $77 \mathrm{~B}$ permits a proceeding for reorganization to be filed by a debtor or its creditors, as provided in subdivision $a$, in a case where a receiver or trustee has been appointed by a federal, state or territorial court for all or any part of the debtor's property. ${ }^{85}$ It has been asserted that the effect of this provision is to broaden the scope of Section $77 B$, in the situations specified, to include banks, insurance companies, and building and loan associations, even though such corporations may not be adjudicated bankrupt under Section 4 of the Act. ${ }^{86}$ The reference to subdivision $a$, it is contended, relates merely to the procedure fixed by that subdivision for the filing of a reorganization proceeding, and not to the classes of corporations amenable to Section 77 B..$^{87}$

However, it is greatly to be doubted that the proper construction of subdivision $i$ is as contended. Its primary purpose apparently is to provide for possession of assets, protection of obligations, and payment of administration costs, in cases where an equity receivership is followed by a reorganization under Section $77 \mathrm{~B}$. The particular provision under consideration would seem to be merely incidental, and intended to make entirely clear the fact that a corporation may avail itself of the benefits of Section $77 B$, or be subjected to its provisions, despite the pendency of a prior equity receivership, and regardless of the duration of such a prior receivership. ${ }^{88}$ It is hardly to be supposed that the fundamental policy of Section $77 \mathrm{~B}$, which

85. 48 STAT. 920, II U. S. C. A. § 207 (i) (Supp. I934) : "If a receiver or trustee of all or any part of the property of a corporation has been appointed by a Federal, State, or Territorial court, whether before or after this amendatory Act takes effect a petition or answer may be filed under this section at any time thereafter by the corporation, or its creditors as provided in subdivision (a) of this section and if such petition or answer is approved, the trustee or trustees appointed under this section, or the debtor if no trustee is appointed, shall be entitled forthwith to possession of and vested with title to such property, and the judge shall make such orders as he may deem equitable for the protection of obligations incurred by the receiver or prior trustee and for the payment of such reasonable administrative expenses and allowances in the prior proceeding as may be fixed by the court appointing said receiver or prior trustee. . . ."

86. McKeown and Langeiuttig, Federal Debtor Relief Laws (1935) rog-ilo.

87. Id. at IIO.

88. It has been held that an involuntary bankruptcy petition must be filed within four months of an equity receivership, and that in case of failure to act within such period, the jurisdiction of the state court, if rightfully acquired, becomes fixed and not subject to interference. In re Knight, I25 Fed. 35 (W. D. Ky. 1903) ; Lyon v. Russe11, 4I App. D. C. 554 (I9I4) ; I COLLIER, BANKRUPTCY (I3th ed. I924) I65, I66. In the case of a voluntary bankruptcy petition following an equity receivership, the decisions are in conflict. In some jurisdictions, it is held that such a petition may be filed at any time after an equity receivership, despite the lapse of more than four months. Zeitinger v. Hargadine-McKittrick Dry Goods Co., 244 Fed. 7I9 (C. C. A. 8th, I9I7) ; Struthers Furnace Co. v. Grant, 30 F. (2d) 576 (C. C. A. 6th, 1929). Contra: In re Richardson's Estate, 294 Fed. 349 (N. D. Tex. I923); In re Hammond Motors Co., I3 F. (2d) 901 (E. D. La. I926). 
excludes corporations such as cannot be adjudicated bankrupt under Section 4 of the Act, is to be abrogated merely by virtue of a prior equity receivership. There is no logical reason to permit the reorganization under Section $77 \mathrm{~B}$ of a bank, insurance company, or building and loan association which is already in an equity proceeding, and to deny a reorganization to such a corporation where there is no pending equity proceeding. If the effect of subdivision $i$ is as contended, reorganization jurisdiction could be conferred over banks, insurance companies and building and loan associations, by the simple device of instituting an equity receivership and following it immediately by a petition under Section $77 \mathrm{~B}$. Such a situation would obviously be anomalous; it cannot be presumed that Congress intended to accomplish by indirection what it could have achieved directly. It is, therefore, much more logical to read subdivision $i$ in conjunction with subdivision $a$, not merely from the limited aspect of procedure, but generally, and thus to restrict subdivision $i$ by interpretation to such corporations as may reorganize under subdivision $a$.

\section{Conclusion}

From the foregoing discussion, it would seem that a voluntary proceeding under Section $77 B$ may be filed by any corporation, in the broad sense as defined in Section I (6) of the Bankruptcy Act, which could become a bankrupt under Section 4 of the Act (as modified by the definition of "railroad corporation" in Section 77), except a railroad or railway amenable to Section 77 or deriving more than twenty per cent. of its operating revenue from operation in conjunction with a municipality. It would appear, also, that in the case of an involuntary proceeding under Section $77 \mathrm{~B}$, despite the absence of a specific similar restriction, creditors may petition for the reorganization only of corporations of the same classes as may file a voluntary proceeding. The category of the corporations amenable to the Section is not enlarged either by the "present operations" proviso, or by subdivision $i$ relating to corporations in prior receivership. In the case of subsidiaries, however, the broad construction of "corporation" cannot be adopted; by virtue of the express language used, it would seem that only a stock corporation in the strict sense may intervene in the reorganization proceeding of its principal.

It is regrettable that a legislative measure as important as Section $77 \mathrm{~B}$ should have been drafted without the utmost regard for clarity and uniformity. Unfortunately, the general tenor of the Section creates a strong impression of a basic design that it shall apply only to stock corporations; and in other respects the language of the Section raises the several problems indicated in this discussion. Should the courts fall into confusion in the determination of these various problems, it may become necessary for Congress to clarify the provisions of Section $77 \mathrm{~B}$ by further amendment. 